\title{
HUBUNGAN PRODUK Ca $x$ P DENGAN KADAR C-TERMINAL CROSS LINKING TELOPEPTIDE TYPE I COLLAGEN PADA SUBJEK PENYAKIT GINJAL KRONIK YANG MENJALANI HEMODIALISA RUTIN
}

\author{
${ }^{1}$ Agung Pratama \\ ${ }^{2}$ Emma Sy. Moeis \\ ${ }^{2}$ Veny Mandang \\ ${ }^{1}$ Kandidat Skripsi Fakultas Kedokteran Universitas Sam Ratulangi Manado \\ ${ }^{2}$ Bagian Ilmu Penyakit Dalam Fakultas Kedokteran Universitas Sam Ratulangi Manado \\ Email: agung100111225@gmail.com
}

\begin{abstract}
Abstrak: Penyakit Ginjal Kronik (PGK) merupakan masalah kesehatan yang telah mencakup seluruh masyarakat dunia dan berdampak pada jutaan orang dari seluruh ras dan etnis yang terjadi ketika kondisi fungsi ginjal mengalami gangguan dan hemodialisis merupakan terapi pengganti ginjal yang umum dilakukan. Ketidakseimbangan elektrolit (kalsium dan fosfat) di dalam tubuh akan berlangsung terus menerus dan irreversible pada PGK. CTX adalah biomarker serum yang digunakan untuk mengukur tingkat regenerasi tulang. Tujuan: Penelitian ini bertujuan untuk mengetahui hubungan produk Ca x P dengan kadar CTX pada subjek PGK yang menjalani hemodialisis rutin. Metode: Penelitian ini bersifat deskriptif/analitik dengan rancangan potong lintang. Data diolah dengan cara disusun dalam bentuk tabel dan grafik. Hasil: Dari penelitian ini tampak bahwa seluruh responden memiliki kadar CTX lebih diatas normal yaitu sebanyak 20 orang (100 \%). Pada frekuensi hemodialisa yang dilakukan antara 192 - 239 x dan 288 - 335 x paling banyak ditemukan masingmasing sebanyak 6 orang (30\%) dan pada frekuensi hemodialisa yang dilakukan antara $240-287 \mathrm{x}$ sebanyak 5 orang (25\%) diikuti frekuensi HD > 336 x sebanyak 3 orang (15\%) yang terdiri dari 1 lakilaki (5\%) dan 2 perempuan (10\%). Simpulan: Rata-rata nilai serum kalsium pada subjek penyakit ginjal kronik yang menjalani hemodialisis rutin adalah 7,96 mg/dl. Rata-rata nilai serum fosfat pada subjek penyakit ginjal kronik yang menjalani hemodialisis rutin adalah 7,26 mg/dl. Terdapat hubungan positif hasil produk CaP dengan kadar CTX, walaupun secara statistik tidak bermakna.
\end{abstract}

Kata kunci: Kalsium serum, Fosfat serum, CTX, PGK, Hemodialisis

\begin{abstract}
Chronic kidney disease (CKD) is a health concern that covered everyone in the world and affected millions of people from various race and ethnics in which the kidney did not functioning properly thus hemodialysis is a kidney replacement therapy which often performed. There will always be electrolite imbalance (Calcium and phosphat) in the body and this is irreversible in CKD. CTX is a serum biomarker that has been used to measure bone regeneration rate. Objectives: This study aims to asses the relation between Ca x P product and CTX level on CKD subjects who undergo routine hemodialysis. Methods: This study is a descriptive/ analysis study using a cross link design. Data processing was done by using table and charts. Results: From this study we found that all of the respondent who have an above normal CTX level are 20 people (100\%). Hemodialysis frequency that have been done is between 192-239 times and 288-335 times which is the most frequent among 6 people (30\%) and on hemodialysis frequency that have been done between 240-287 times on 5 people (25) followed by HD frequency $>336$ times on 3 people (15\%); 1 male (5\%) and 2 female $(10 \%)$. Conclusions: The value of mean calcium serum on subjects with CKD who undergo routine hemodialysis is $7,96 \mathrm{mg} / \mathrm{dL}$. Value of mean phosphat serum on subjects with CKD who undergo routine hemodialysis is $7,26 \mathrm{mg} / \mathrm{dL}$. We found that there is a positive relationship between CaP product and CTX level, although not significant statistically.
\end{abstract}

Keywords: serum calcium, serum phosphat, CTX, CKD, hemodialysis 

Penyakit Ginjal Kronik (PGK) merupakan masalah kesehatan yang telah mencakup seluruh masyarakat dunia dan berdampak pada jutaan orang dari seluruh ras dan etnis yang terjadi ketika kondisi fungsi ginjal mengalami gangguan dalam mengeksresikan bahan-bahan yang tidak diperlukan tubuh secara ireversibel dan dalam jangka waktu lama. Insiden dan prevalensi PGK di seluruh dunia meningkat tajam pada 3 dekade terakhir. Di Amerika Serikat prevalensi PGK tahap 1-4 menurut National Health and Nutrition Education Survey (NHANES) antara tahun 1999 dan 2006 adalah 26 juta (13\%) dari sekitar 200 juta penduduk Amerika Serikat yang berusia 20 tahun lebih, dan dari jumlah tersebut, 65,3\% berada pada stadium CKD 3 dan 4. ${ }^{1,2}$

Studi epidemiologi klinis menunjukkan bahwa PGK menempati urutan pertama dari semua panyakit ginjal di Indonesia. Hal ini disebabkan karena kurangnya kesadaran individu terhadap deteksi dini PGK. Selain sulit disembuhkan, biaya perawatan dan pengobatannya pun mahal, belum lagi kebanyakan pasien PGK tahap awal tidak menunjukkan gejala klinis yang berarti. Menurut data dari The United States Renal Data System (USRDS) tahun 2009 PGK tahap akhir (GGTA) sering ditemukan dan prevalensinya sekitar 10-13 \%. Di Amerika Serikat jumlahnya mencapai 25 juta orang, dan di Indonesia diperkirakan 12,5 \% atau sekitar 18 juta orang. ${ }^{3-5}$

Gagalnya faal ginjal dapat diukur dengan turunnya bersihan kreatinin, dimana nilai laju filtrasi glomerulus kurang dari 15 $\mathrm{ml} /$ menit pada tahap gagal ginjal. Hipertensi dan diabetes adalah penyebab tersering dari PGK dan secara langsung berhubungan dengan resiko kardiovaskuler. Pasien PGK khususnya stadium terminal apapun etiologinya memerlukan pengobatan khusus yang disebut pengobatan atau terapi pengganti ginjal (TPG). Pada umumnya TPG yang paling banyak dilakukan di Indonesia adalah Hemodialisis (HD). Di Indonesia jumlah pasien PGK meningkat pesat dengan angka kejadian gagal ginjal yang menjalani hemodialisis dari tahun
2002 sampai 2006 secara berturut-turut adalah 2077, 2039, 2594, 3556, dan 4344. ${ }^{3,4}$

Hemodialisis adalah suatu proses yang digunakan untuk mengeluarkan cairan dan produk limbah dari dalam tubuh ketika ginjal tidak mampu melaksanakan fungsi utamanya yaitu menyaring dan membuang zat-zat sisa metabolisme tubuh dari darah dan menjaga keseimbangan cairan serta elektrolit (misalnya kalsium, natrium, dan kalium) dalam darah. Gangguan elektrolit terjadi pada saat LFG: $60 \mathrm{ml} / \mathrm{menit} / 1,73 \mathrm{~m}^{2}$ dan gangguan ini lebih jelas pada stadium lanjut. Pasien PGK yang menjalani hemodialisis rutin sering mengalami inflamasi, peningkatan kreatinin, ketidakseimbangan elektrolit, malnutrisi karena kurangnya asupan protein, kehilangan simpanan energi termasuk jaringan lemak dan protein tubuh, albumin serum, transferin dan protein tubuh viseral lainnya yang mengarah pada penurunan kualitas hidup sehingga memiliki morbiditas dan mortalitas yang lebih tinggi dibanding populasi normal. ${ }^{6-10}$

Ketidakseimbangan elektrolit (kalsium dan fosfat) di dalam tubuh akan berlangsung terus menerus dan irreversibel. Keseimbangan kalsium fosfat dipertahankan oleh interaksi antara hormon paratiroid $(\mathrm{PTH})$, vitamin D dan kalsitonin melalui mekanisme complex feedback loops yang bekerja di tulang, ginjal dan usus, dimana PTH bertanggung jawab sebagai pengendali utama. Bila penderita GGK dapat bertahan cukup lama, maka ketidakseimbangan kalsium dan fosfat yang disertai gangguan mineralisasi rangka tak mungkin terelakkan dan biasanya dikenal sebagai ginjal osteodistrofi atau renal bone disease. Gangguan mineralisasi tulang ini membuat tulang memiliki struktur yang lemah dan dapat mengalami fraktur atau perubahan bentuk bila mendapat tekanan. Gangguan mineralisasi tulang yang paling sering ditemukan yaitu osteomalasia (60\%) dan osteitis fibrosa (30\%). ${ }^{11-13}$

Kejadian patah tulang belakang dan pinggul meningkat 2 kali lipat pada usia lebih dari 60 tahun sedangkan patah tulang pada pergelangan tangan mengalami 
Pratama, Moeis, Mandang; Hubungan Produk Ca x P...

penurunan. Dalam fisiologi tulang, telopeptide C-terminal (CTX) adalah biomarker serum yang digunakan untuk mengukur tingkat regenerasi tulang. Serum CTX dipilih karena sangat berkorelasi dengan tingkat turnover tulang dan spesifik untuk resorpsi tulang dari pada tes lainnya yang tersedia saat ini. ${ }^{14-16}$

\section{METODE}

Penelitian ini bersifat deskriptif /analitik dengan rancangan potong lintang. Penelitian dilakukan di Unit Hemodialisis Bagian/SMF Ilmu Penyakit Dalam FK Unsrat/BLU RSUP Prof. DR. R. D. Kandou Manado. Penelitian dilakukan pada bulan Desember 2013 sampai dengan Februari 2014. Responden penelitian adalah seluruh pasien PGK yang menjalani tindakan hemodialisis di Unit Hemodialisis Bagian/SMF Ilmu Penyakit Dalam FK Unsrat/BLU RSUP Prof. DR. R. D. Kandou Manado. Jumlah responden dalam penelitian ini sebanyak 20 orang.

Data dianalisis menggunakan software pengolahan data yaitu SPSS versi 20 kemudian setiap variabel penelitian dideskripsikan dengan menggunakan tabel untuk menggambarkan informasi secara umum tentang variabel penelitian.

\section{HASIL}

Dari 20 sampel yang diambil pada penelitian yang dilakukan di bagian Hemodialisa RSUP Prof. Dr. R. D. Kandou Manado periode Desember 2013 - Februari 2014 diperoleh hasil sebagai berikut:

Tabel 1 menunjukkan data rerata nilai kalsium $(7,96)$, fosfat $(7,26)$, CTX $(4,51)$, frekuensi tindakan HD (298x). 20 subjek penelitian menunjukkan rerata kadar $\mathrm{Ca}$ serum menurun sedangkan rerata $\mathrm{P}$ serum mengalami peningkatan dari kadar normal, dan hasil produk Ca x P >55 terdiri dari 11 orang (55 \%) dengan rerata 73,05.

Pada Tabel 2 terlihat bahwa kelompok umur yang paling banyak yaitu pada kelompok umur 40-49 tahun dan 60-69 tahun, masing-masing sebanyak 6 orang
(30\%), sedangkan kelompok umur $>70$ tahun hanya diwakili oleh 1 orang (5\%).

Tabel 1. Karakteristik Responden Penelitian Pasien Penyakit Ginjal Kronik di RSUP Prof. Dr. R. D. Kandou Manado Periode Desember 2013 - Februari 2014

\begin{tabular}{|c|c|c|c|c|c|c|}
\hline \multicolumn{2}{|c|}{ Variabel } & $\mathrm{N}$ & Min & Max & Rerata & $\mathrm{SD}$ \\
\hline \multicolumn{2}{|c|}{ Umur (tahun) } & 20 & 36 & 73 & 51,3 & 11,95 \\
\hline \multirow{2}{*}{$\begin{array}{l}\text { Jenis } \\
\text { kelamin }\end{array}$} & $\sigma^{\lambda}$ & 8 & - & - & - & - \\
\hline & 우 & 12 & - & - & - & - \\
\hline \multirow{2}{*}{\multicolumn{2}{|c|}{$\begin{array}{c}\text { Ca serum } \\
\text { (mg/dl) } \\
\text { P serum } \\
\text { (mg/dl) }\end{array}$}} & 20 & 5,51 & 10,7 & 7,96 & 1,26 \\
\hline & & 20 & 3,7 & 11,8 & 7,26 & 2,14 \\
\hline \multirow{2}{*}{$\begin{array}{l}\text { Produk } \\
\text { Ca x P } \\
\text { (mg/dl) }\end{array}$} & $\leq 55$ & 9 & 29,23 & 52,2 & 40,48 & 9.12 \\
\hline & $>55$ & 11 & 55,8 & 126,26 & 73,05 & 19,33 \\
\hline \multicolumn{2}{|c|}{$\begin{array}{l}\text { CTX (ng/ml) } \\
\text { Jumlah }\end{array}$} & 20 & 1,28 & 6 & 4,51 & 1,55 \\
\hline \multicolumn{2}{|c|}{$\begin{array}{l}\text { tindakan HD } \\
\text { (kali) }\end{array}$} & 20 & 208 & 624 & 298,35 & 112,15 \\
\hline
\end{tabular}

Tabel 2. Distribusi Jenis Kelamin Berdasarkan Umur pada Pasien Penderita Penyakit Ginjal Kronik di RSUP Prof. Dr. R. D. Kandou Manado Periode Desember 2013 - Februari 2014

\begin{tabular}{ccccc}
\hline \multirow{2}{*}{$\begin{array}{c}\text { Umur } \\
\text { (tahun) }\end{array}$} & \multicolumn{4}{c}{ Jumlah } \\
\cline { 2 - 5 } & Laki -laki & N (\%) & Perempuan & N (\%) \\
\hline $30-39$ & 4 & 20 & 1 & 5 \\
$40-49$ & 2 & 10 & 4 & 20 \\
$50-59$ & - & - & 2 & 10 \\
$60-69$ & 2 & 10 & 4 & 20 \\
$>70$ & - & - & 1 & 5 \\
Total & 8 & 40 & 12 & 60 \\
\hline
\end{tabular}

Pada Tabel 3 dapat dilihat bahwa nilai calsium darah dari semua kelompok umur pada pasien penyakit ginjal kronik yang menjalani hemodialisa rutin didapatkan hiperkalsemia pada 4 orang (20 \%) laki-laki kelompok umur 30-69 tahun dan 7 orang (35\%) perempuan pada semua kelompok umur sedangkan 3 orang (15\%) laki-laki dan 5 orang (25\%) perempuan dengan normokalsemia dan hanya 1 orang (5\%) laki-laki dengan hiperkalsemia. 
Tabel 3. Distribusi Kadar Kalsium Berdasarkan Kelompok Umur dan Jenis Kelamin pada Pasien Penderita Penyakit Ginjal Kronik di RSUP Prof. Dr. R. D. Kandou Manado Periode Desember 2013 - Februari 2014

\begin{tabular}{|c|c|c|c|c|c|}
\hline \multicolumn{2}{|c|}{$\begin{array}{l}\text { Jenis } \\
\text { kelamin } \\
\text { dan } \\
\text { Umur } \\
\text { (tahun) }\end{array}$} & $\begin{array}{c}\text { Hipo } \\
\text { kalsemia } \\
\text { (mg/dl) }\end{array}$ & $\begin{array}{c}\text { Normo } \\
\text { kalsemia } \\
\text { (mg/dl) }\end{array}$ & $\begin{array}{c}\text { Hiper } \\
\text { kalsemia } \\
\text { (mg/dl) }\end{array}$ & $\begin{array}{c}\mathbf{N} \\
(\%)\end{array}$ \\
\hline \multirow{6}{*}{ 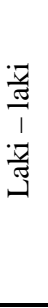 } & $30-39$ & 2 & 1 & 1 & 20 \\
\hline & $40-49$ & 1 & 1 & - & 10 \\
\hline & 50-59 & - & - & - & - \\
\hline & 60-69 & 1 & 1 & - & 10 \\
\hline & $>70$ & - & - & - & - \\
\hline & Total & 4 & 3 & 1 & 40 \\
\hline \multirow{6}{*}{ 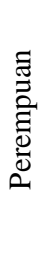 } & 30-39 & 1 & - & - & 5 \\
\hline & $40-49$ & 1 & 3 & - & 20 \\
\hline & $50-59$ & 1 & 1 & - & 10 \\
\hline & $60-69$ & 3 & 1 & - & 20 \\
\hline & $>70$ & 1 & - & - & 5 \\
\hline & Total & 7 & 5 & - & 60 \\
\hline
\end{tabular}

Tabel 4. Distribusi Kadar Fosfat Berdasarkan Kelompok Umur dan Jenis Kelamin pada Pasien Penderita Penyakit Ginjal Kronik di RSUP Prof. Dr. R. D. Kandou Manado Periode Desember 2013 - Februari 2014

\begin{tabular}{|c|c|c|c|c|c|}
\hline $\begin{array}{r}\text { ke } \\
\text { (t }\end{array}$ & $\begin{array}{l}\text { Jenis } \\
\text { elamin } \\
\text { dan } \\
\text { Umur } \\
\text { tahun) } \\
\end{array}$ & $\begin{array}{c}\text { Hipofosf } \\
\text { atemia } \\
\text { (mg/dl) }\end{array}$ & $\begin{array}{l}\text { Normofos } \\
\text { fatemia } \\
\text { (mg/dl) }\end{array}$ & $\begin{array}{c}\text { Hiperfos } \\
\text { fatemia } \\
\text { (mg/dl) }\end{array}$ & $\begin{array}{c}\mathrm{N} \\
(\%)\end{array}$ \\
\hline \multirow{6}{*}{ 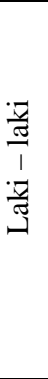 } & $\begin{array}{c}30- \\
39\end{array}$ & - & - & 4 & 20 \\
\hline & $\begin{array}{c}40- \\
49\end{array}$ & - & - & 2 & 10 \\
\hline & $\begin{array}{c}50- \\
59\end{array}$ & - & - & - & - \\
\hline & $\begin{array}{c}60- \\
69\end{array}$ & - & - & 2 & 10 \\
\hline & $>70$ & - & - & - & - \\
\hline & Total & - & - & 8 & 40 \\
\hline \multirow{6}{*}{ 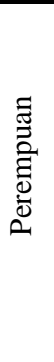 } & $\begin{array}{c}30- \\
39\end{array}$ & - & - & 1 & 5 \\
\hline & $\begin{array}{c}40- \\
49\end{array}$ & - & - & 4 & 20 \\
\hline & $\begin{array}{c}50- \\
59\end{array}$ & - & - & 2 & 10 \\
\hline & $\begin{array}{c}60- \\
69\end{array}$ & - & 1 & 3 & 20 \\
\hline & $>70$ & - & 1 & - & 5 \\
\hline & Total & - & 2 & 10 & 60 \\
\hline
\end{tabular}

Pada Tabel 4 menunjukkan 18 orang (90\%) dengan hiperfosfatemia terdiri dari 8 orang (40\%) laki-laki dan 10 orang (50\%) perempuan sedangkan 2 orang (10\%) perempuan normofosfatemia dan tidak terdapat hipofosfatemia.

Tabel 5. Distribusi Kadar Ca x P Berdasarkan Kelompok Umur dan Jenis Kelamin pada Pasien Penderita Penyakit Ginjal Kronik di RSUP Prof. Dr. R. D. Kandou Manado Periode Desember 2013 - Februari 2014

\begin{tabular}{|c|c|c|c|c|}
\hline \multirow{2}{*}{\multicolumn{2}{|c|}{$\begin{array}{c}\text { Jenis } \\
\text { kelamin dan } \\
\text { Umur } \\
\text { (tahun) }\end{array}$}} & \multicolumn{3}{|c|}{ Hasil produk Ca $\times \mathrm{P}$} \\
\hline & & $\begin{array}{c}\leq 55 \\
(\mathrm{mg} / \mathrm{dl})\end{array}$ & $\begin{array}{c}>55 \\
(\mathrm{mg} / \mathrm{dl})\end{array}$ & N (\%) \\
\hline \multirow{6}{*}{ 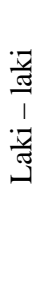 } & $30-39$ & 2 & 2 & 20 \\
\hline & $40-49$ & - & 2 & 10 \\
\hline & $50-59$ & - & - & - \\
\hline & $60-69$ & - & 2 & 10 \\
\hline & $>70$ & - & - & - \\
\hline & Total & 2 & 6 & 40 \\
\hline \multirow{6}{*}{ 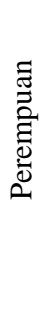 } & $30-39$ & - & 1 & 5 \\
\hline & $40-49$ & 2 & 2 & 20 \\
\hline & $50-59$ & - & 2 & 10 \\
\hline & $60-69$ & 4 & - & 20 \\
\hline & $>70$ & 1 & - & 5 \\
\hline & Total & 7 & 5 & 60 \\
\hline
\end{tabular}

Pada Tabel 5 menunjukkan 9 orang (45\%) dengan hasil produk $\mathrm{Ca}$ x $\mathrm{P} \leq 55$ terdiri dari 2 orang (10\%) laki-laki dan 7 orang (35\%) perempuan sedangkan 11 orang (55\%) yang terdiri dari 6 orang (30\%) laki-laki dan 5 orang (25\%) perempuan memiliki hasil produk Ca x P $>55$.

Pada Tabel 6 tampak bahwa frekuensi hemodialisa yang dilakukan antara 192239x dan 288-335x paling banyak ditemukan yaitu sebanyak 6 orang (30\%) sedangkan pada kelompok umur 40-49 dan 60-69 yang telah menjalani hemodialisa >336 x semuanya diwakili oleh perempuan yaitu sebanyak 2 orang (10\%). 
Pratama, Moeis, Mandang; Hubungan Produk Ca x P...

Tabel 6. Distribusi Frekuensi Tindakan HD Berdasarkan Kelompok Umur dan Jenis Kelamin pada Pasien Penderita Penyakit Ginjal Kronik di RSUP Prof. Dr. R. D. Kandou Manado Periode Desember 2013 - Februari 2014

\begin{tabular}{|c|c|c|c|c|c|c|c|c|c|}
\hline \multirow{3}{*}{$\begin{array}{c}\text { Umur } \\
\text { (tahun) }\end{array}$} & \multicolumn{9}{|c|}{ Frekuensi Tindakan HD } \\
\hline & \multicolumn{2}{|c|}{$\begin{array}{l}192- \\
239 x\end{array}$} & \multicolumn{2}{|c|}{$\begin{array}{l}240- \\
287 x\end{array}$} & \multicolumn{2}{|c|}{$\begin{array}{l}288- \\
335 x\end{array}$} & \multicolumn{2}{|c|}{$\begin{array}{c}>336 \\
x\end{array}$} & \multirow[t]{2}{*}{$\begin{array}{c}\mathrm{N} \\
(\%)\end{array}$} \\
\hline & $\hat{0}$ & 우 & $\hat{0}$ & q & $\widehat{\sigma}$ & o & $\hat{0}$ & 우 & \\
\hline $30-39$ & 1 & 1 & 2 & - & - & - & 1 & - & 25 \\
\hline $40-49$ & 1 & - & - & 1 & 1 & 2 & - & 1 & 30 \\
\hline $50-59$ & - & 1 & - & - & - & 1 & - & - & 10 \\
\hline $60-69$ & - & 1 & - & 2 & 2 & - & - & 1 & 30 \\
\hline$>70$ & - & 1 & - & - & - & - & - & - & 5 \\
\hline Total & 2 & 4 & 2 & 3 & 3 & 3 & 1 & 2 & 100 \\
\hline
\end{tabular}

Tabel 7. Distribusi Frekuensi Tindakan HD Berdasarkan Kadar Kalsium dan Jenis Kelamin pada Pasien Penderita Penyakit Ginjal Kronik di RSUP Prof. Dr. R. D. Kandou Manado Periode Desember 2013 - Februari 2014

\begin{tabular}{|c|c|c|c|c|c|c|c|c|c|}
\hline \multirow{3}{*}{$\begin{array}{c}\text { Kalsium } \\
\text { (mg/dl) }\end{array}$} & \multicolumn{9}{|c|}{ Frekuensi Tindakan HD } \\
\hline & \multicolumn{2}{|c|}{$\begin{array}{l}192- \\
239 x \\
\end{array}$} & \multicolumn{2}{|c|}{$\begin{array}{l}240- \\
287 x \\
\end{array}$} & \multicolumn{2}{|c|}{$\begin{array}{l}288- \\
335 x\end{array}$} & \multicolumn{2}{|c|}{$\begin{array}{c}>336 \\
x \\
\end{array}$} & \multirow[t]{2}{*}{$\begin{array}{r} \\
(\%) \\
\end{array}$} \\
\hline & $\hat{0}$ & q & $0^{\lambda}$ & q & $\hat{0}$ & q & $\hat{0}$ & 우 & \\
\hline $\begin{array}{l}\text { Hipokals } \\
\text { emia }\end{array}$ & 1 & 4 & 1 & 3 & 1 & - & 1 & 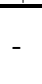 & 55 \\
\hline $\begin{array}{l}\text { Normoka } \\
\text { lsemia }\end{array}$ & 1 & - & - & - & 2 & 3 & - & 2 & 40 \\
\hline $\begin{array}{l}\text { Hiperkals } \\
\text { emia }\end{array}$ & - & - & 1 & - & - & - & - & - & 5 \\
\hline Total & 2 & 4 & 2 & 3 & 3 & 3 & 1 & 2 & 100 \\
\hline
\end{tabular}

Pada Tabel 7 terlihat sebagian besar pasien penyakit ginjal kronik yang menjalani hemodialisa memiliki kadar hipokalsemia, yaitu sebanyak 11 orang (55\%) yang terdiri dari 4 laki-laki (20\%) dan 7 perempuan (35\%) dan 8 orang (40\%) yang terdiri dari 3 laki-laki (15\%) dan 5 perempuan (25\%) memiliki kadar normokalsemia, sisanya 1 orang laki-laki (5\%) mewakili hiperkalsemia.

Pada Tabel 8 dapat dilihat bahwa kadar fosfat darah dari semua kelompok frekuensi tindakan HD pada pasien penyakit ginjal kronik yang menjalani hemodialisa rutin paling banyak berada kadar hiperfosfatemia (> 4,5 mg/dl) yaitu sebanyak 18 orang (90\%) terdiri dari 8 laki-laki (40\%) dan 10 perempuan (50\%) sedangkan nilai normofosfatemia (2,5-4,5 mg/dl) yang terdiri dari 2 orang (10\%) diwakili oleh perempuan.

Tabel 8. Distribusi Frekuensi Tindakan HD Berdasarkan Kadar Fosfat dan Jenis Kelamin pada Pasien Penderita Penyakit Ginjal Kronik di RSUP Prof. Dr. R. D. Kandou Manado Periode Desember 2013 - Februari 2014

\begin{tabular}{|c|c|c|c|c|c|c|c|c|c|}
\hline \multirow{3}{*}{$\begin{array}{l}\text { Fosfat } \\
\text { (mg/dl) }\end{array}$} & \multicolumn{9}{|c|}{ Frekuensi Tindakan HD } \\
\hline & \multicolumn{2}{|c|}{$\begin{array}{l}192- \\
239 x\end{array}$} & \multicolumn{2}{|c|}{$\begin{array}{l}240- \\
287 x\end{array}$} & \multicolumn{2}{|c|}{$\begin{array}{l}288- \\
335 x\end{array}$} & \multicolumn{2}{|c|}{$>336$} & $\begin{array}{c}\mathrm{N} \\
(\%) \\
\end{array}$ \\
\hline & $\pi$ & 우 & $\hat{0}$ & q & 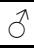 & 우 & d & 우 & \\
\hline $\begin{array}{l}\text { Hipofosfa } \\
\text { temia }\end{array}$ & - & - & - & - & - & - & - & - & - \\
\hline $\begin{array}{l}\text { Normofo } \\
\text { sfatemia }\end{array}$ & - & 2 & - & - & - & - & 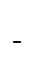 & - & 10 \\
\hline $\begin{array}{l}\text { Hiperfosf } \\
\text { atemia }\end{array}$ & 2 & 2 & 2 & 3 & 3 & 3 & 1 & 2 & 90 \\
\hline Total & 2 & 4 & 2 & 3 & 3 & 3 & 1 & 2 & 100 \\
\hline
\end{tabular}

Tabel 9. Distribusi Frekuensi Tindakan HD Berdasarkan Kadar Ca x P dan Jenis Kelamin pada Pasien Penderita Penyakit Ginjal Kronik di RSUP Prof. Dr. R. D. Kandou Manado Periode Desember 2013 - Februari 2014

\begin{tabular}{|c|c|c|c|c|c|c|c|c|c|}
\hline \multirow{3}{*}{$\begin{array}{c}\text { Ca x P } \\
(\mathrm{mg} / \mathrm{dl})\end{array}$} & \multicolumn{9}{|c|}{ Frekuensi Tindakan HD } \\
\hline & \multicolumn{2}{|c|}{$\begin{array}{l}192- \\
239 \times\end{array}$} & \multicolumn{2}{|c|}{$\begin{array}{l}240- \\
287 \times \\
\end{array}$} & \multicolumn{2}{|c|}{$\begin{array}{l}288- \\
335 \times\end{array}$} & \multicolumn{2}{|c|}{$>336$} & \multirow[t]{2}{*}{$\begin{array}{c}N \\
(\%) \\
\end{array}$} \\
\hline & $\hat{0}$ & 우 & $\hat{0}$ & 9 & 0 & 9 & 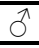 & 우․ & \\
\hline$\leq 55$ & - & 2 & 1 & 3 & - & 1 & 1 & 1 & 45 \\
\hline$>55$ & 2 & 2 & 1 & - & 3 & 2 & - & 1 & 55 \\
\hline Total & 2 & 4 & 2 & 3 & 3 & 3 & 1 & 2 & 100 \\
\hline
\end{tabular}

Tabel 10. Distribusi Frekuensi Tindakan HD Berdasarkan Kadar CTX dan Jenis Kelamin pada Pasien Penderita Penyakit Ginjal Kronik di RSUP Prof. Dr. R. D. Kandou Manado Periode Desember 2013 - Februari 2014

\begin{tabular}{|c|c|c|c|c|c|c|c|c|c|}
\hline \multirow{3}{*}{$\begin{array}{c}\text { CTX } \\
\text { (ng/dl) }\end{array}$} & \multicolumn{9}{|c|}{ Frekuensi Tindakan HD } \\
\hline & \multicolumn{2}{|c|}{$\begin{array}{l}192- \\
239 x\end{array}$} & \multicolumn{2}{|c|}{$\begin{array}{l}240- \\
287 x\end{array}$} & \multicolumn{2}{|c|}{$\begin{array}{l}288- \\
335 x\end{array}$} & \multicolumn{2}{|c|}{$\begin{array}{c}>336 \\
x\end{array}$} & \multirow[t]{2}{*}{$\begin{array}{r}\mathrm{N} \\
(\%)\end{array}$} \\
\hline & 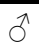 & 우 & $\hat{0}$ & 우 & $\hat{0}$ & q & $\hat{0}$ & 우 & \\
\hline$\sqrt{3}$ & - & - & - & - & - & - & - & - & - \\
\hline Normal & - & - & - & - & - & - & - & - & - \\
\hline 仓 & 2 & 4 & 2 & 3 & 3 & 3 & 1 & 2 & 100 \\
\hline Total & 2 & 4 & 2 & 3 & 3 & 3 & 1 & 2 & 100 \\
\hline
\end{tabular}

Pada Tabel 9 terlihat hasil perkalian $\mathrm{CaP}>55(\mathrm{mg} / \mathrm{dl})$ pada pasien yang sudah menjalani HD antara 288-335 x sebanyak 5 orang (25\%) yang terdiri dari 3 laki-laki (15\%) dan 2 perempuan (10\%) dan untuk 
frekuensi HD antara 192 - 239 x sebanyak 4 orang (20\%) yang terdiri dari 2 laki-laki (10\%) dan 2 perempuan (10\%) sedangkan untuk nilai $\mathrm{CaP} \leq 55(\mathrm{mg} / \mathrm{dl})$ dan sudah menjalani HD sebanyak $>336 x$ masingmasing diwakili oleh 1 laki-laki (5\%) dan 1 perempuan (5\%).

Pada Tabel 10 tampak bahwa seluruh responden memiliki kadar CTX lebih diatas normal yaitu sebanyak 20 orang (100\%). Pada frekuensi hemodialisa yang dilakukan antara 192-239x dan 288-335x paling banyak ditemukan masing-masing sebanyak 6 orang (30\%) dan pada frekuensi hemodialisa yang dilakukan antara 240287x sebanyak 5 orang (25\%) diikuti frekuensi HD >336 x sebanyak 3 orang (15\%) yang terdiri dari 1 laki-laki (5\%) dan 2 perempuan (10\%).

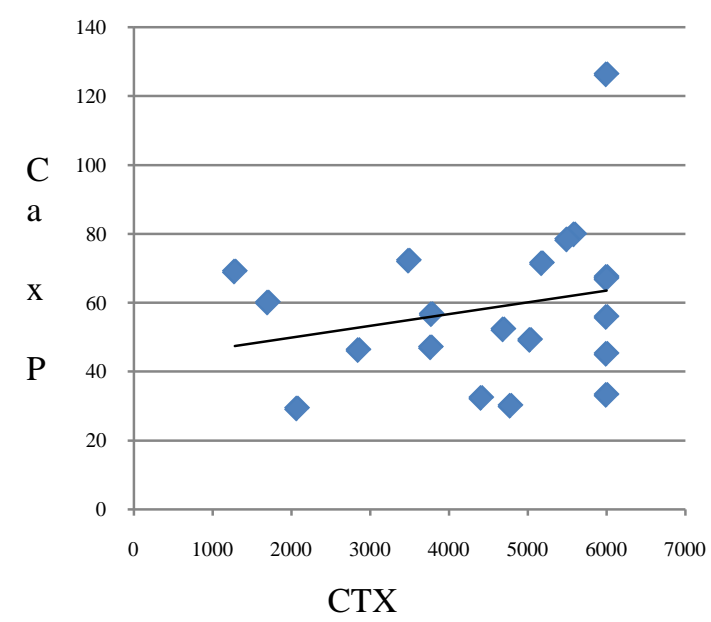

Gambar 1. Distribusi Nilai CTX Berdasarkan Kadar Ca x P.

\section{BAHASAN}

Hasil penelitian hubungan $\mathrm{CaP}$ dengan kadar CTX pada 20 responden yang terdiri 8 pria dan 12 wanita terlihat bahwa nilai rerata dari kalsium yaitu $(7,96)$, fosfat $(7,26)$, CTX (4,51), dan untuk frekuensi tindakan HD (298 x). Berdasarkan uji korelasi antar variabel, didapatkan bahwa $\mathrm{p}>0,05$. Pada penelitian ini hanya korelasi antara kalsium dengan $\mathrm{CaP}$ yang memiliki nilai $\mathrm{p}<0,05$ sedangkan hubungan hasil perkalian $\mathrm{CaP}$ dengan CTX dan lamanya HD, nilai $\mathrm{p}$ semakin jauh dari $<0,05$.

Dari 20 responden, distribusi nilai calcium menunjukkan bahwa sebanyak 4 laki-laki dan 7 perempuan mengalami penurunan nilai normal dari calcium. Hal ini sesuai dengan beberapa literatur yang menyebutkan bahwa pasien dengan gagal ginjal grade 3 atau jika nilai GFR $<40$ $\mathrm{ml} / \mathrm{min}$ per $1.73 \mathrm{~m} 2$ sudah mulai mengalami abnormalitas dan relatif stabil hingga GFR turun dibawah $20 \mathrm{ml} / \mathrm{min}$ per $1.73 \mathrm{~m} 2$, ditambah pada gagal ginjal stadium akhir terjadi kalsiuri. Selain itu dengan bertambahnya usia, maka fungsi ginjal juga akan menurun. Setelah usia 40 tahun, jumlah nefron umumnya berkurang sebanyak 10\% setiap 10 tahun dan LFG berkurang 1 $\mathrm{ml} / \mathrm{min} / 1.73 \mathrm{~m} 2$ setiap tahun, sehingga pada usia 80 tahun jumlah nefron menjadi $40 \%$ lebih sedikit daripada saat berusia 40 tahun dan LFG $40 \mathrm{ml} / \mathrm{menit} / 1.73 \mathrm{~m} 2 .{ }^{17-20}$

Hal yang sama juga terjadi pada nilai fosfat dimana kadar fosfat meningkat pada 18 orang dari 20 responden, sejalan dengan literatur yang mengatakan bahwa serum fosfat mengalami retensi sehingga menyebabkan penurunan kadar kalsium serum. Keadaan ini juga mengganggu pengaktifan Vitamin D3 oleh ginjal, yang diperlukan untuk absorpsi kalsium dari usus. Kedua faktor tersebut cenderung mengakibatkan hipokalsemia. $^{13}$

Meskipun kadar kalsium dan fosfat serum cenderung kembali ke keadaan normal. Tetapi, dengan makin menurunnya GFR kalsium serum yang rendah dan fosfat yang tinggi terus merangsang aktivitas paratiroid dan lama-kelamaan dapat terjadi hiperplasia paratiroid sekunder akibat mekanisme tersebut. ${ }^{13}$

\section{SIMPULAN}

1. Rata-rata nilai serum kalsium pada subjek penyakit ginjal kronik yang menjalani hemodialisis rutin adalah 7,96 $\mathrm{mg} / \mathrm{dl}$.

2. Rata-rata nilai serum fosfat pada subjek penyakit ginjal kronik yang menjalani hemodialisis rutin adalah 7,26 mg/dl. 
Pratama, Moeis, Mandang; Hubungan Produk Ca x P...

3. Terdapat hubungan positif hasil produk $\mathrm{CaP}$ dengan kadar CTX, walaupun secara statistik tidak bermakna.

\section{SARAN}

1. Diharapkan penelitian ini dapat dijadikan sebagai masukan bagi penderita PGK agar dilakukan penganan dini untuk mencegah regenerasi tulang dengan mengkonsumsi obat-obat pengikat fosfat.

\section{DAFTAR PUSTAKA}

1. De Boer IH, Rue TC, Hall YN, Heagerty PJ, Weiss NS, Himmelfarb J. Temporal trends in the prevalence of diabetic kidney disease in the United States. JAMA. Jun 22 2011;305(24): 2532-2539.

2. US Renal Data System. USRDS 2011 Annual Data Report: Atlas of Chronic Kidney Disease and End-Stage Renal Disease in the United States. Am J Kidney Dis. 2012;59(1)(suppl 1):e1-e420.

3. George L. Bakris and Eberhard Ritz, Hypertension and Kidney Disease, A Marriage that Should Be Prevented, Kidney International 75, 449-452 (13 February 2009)

4. Hamer RA, El Nahas AM. The burden of chronic kidney disease. $\mathrm{Br}$ Med J 2006;332:563-564.

5. Suhardjono. 2009. Penyakit Ginjal Kronik adalah suatu wabah baru (global epidemic) di seluruh dunia. Annual Meeting Perhimpunan nefrologi Indonesia.1-9.

6. Zadeh KK, Kopple JD, Block G, Humphreys M H. 2001. Association Among SF36 Quality of Life Measures and Nutrition, Hospitalization and Mortality in Hemodialysis. J of the American Society of Nephrology.12:2797- 806.

7. Stenvinkel P. 2000. Are there two types malnutrition in chronic renal failure? Evidence for relationships between malnutrition,inflammation and atherosclerosis (MIA syndrome).Nephrol Dial Transplant.15.953-960.

8. Alam, S., dan Hadibroto, I., 2007, Gagal Ginjal, Gramedia, Jakarta.

9. Little, J.W., 2008, Dental Management of The Medically Compromised Patient, 7th edition, Elsevier, Canada.
10. Soemantri S. 2012. Panduan Lengkap Mencegah Mengobati Serangan Jantung, Stroke, dan Gagal Ginjal. Yogyakarta: Araska.

11. Bricker NS: On the pathogenesis of the uremic state. An exposition of the "trade-off hypothesis.” N Engl J Med 286:1093-1099, 1972

12. Moe $S$, Drueke $T$, Cunningham J, Goodman W, Martin K, Olgaard K, Ott S, Sprague S, Lameire N, Eknoyan G: Definition, evaluation, and classification of renal osteodystrophy: A position statement from Kidney Disease: Improving Global Outcomes (KDIGO). Kidney Int 69: 19451953, 2006

13. Price \& Wilson. 2005. Patofisiologi Konsep Klinis Proses-proses Penyakit Edisi 6. Jakarta: EGC.

14. Compston JE. Osteoporosis. In: Campbell GA, Compston JE, Crisp AJ, eds. The management of common metabolic bone disorders. Cambridge, Cambridge University Press, 1993:29--62.

15. Marx, RE. Oral Bisphosphonate-Induced Osteonecrosis: Risk Factors, Prediction of Risk Using Serum CTX Testing, Prevention, and Treatment, J Oral MaxillofacSurg 2007;65:2397-2410

16. Rosen, HN. Serum CTX. A new marker of bone resorption that shows treatment effect more often than other markers because of low coefficient of variability and large changes with bisphosphonate therapy. Calcif Tissue Int 2000;66:100

17. Colorado Clinical and Translation Science Institute (CCTSI). (online) http://cctsi.ucdenver.edu/ResearchResources /CTRCs/Lists/UCH\%20CTRC\%20Core\%20 Lab\%20Assays/DispForm.aspx?ID= 28

18. Holick MF, Biancuzzo RM, Chen TC et al. Vitamin D2 is as effective as vitamin D3 in maintaining circulating concentrations of 25-hydroxyvitamin D. J Clin Endocrinol Metab 2008; 93: 677-681.

19. Binkley N, Krueger D, Gemar $D$ et al. Correlation among 25-hydroxy-vitamin D assays. J Clin Endocrinol Metab 2008; 93: 1804-1808.

20. Dusso AS, Brown AJ, Slatopolsky E. Vitamin D. Am J Physiol 2005; 289: F8-28. 